\title{
The Effect of COVID - 19 Crisis on Hopelessness, Loneliness and Spiritual Well-Being of Patients with Type 1 and Type 2 Diabetes in Turkey
}

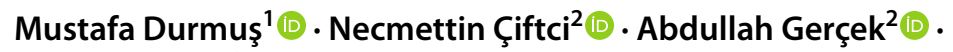 \\ Yusuf Durmuş ${ }^{3}$ iD
}

Accepted: 30 December 2021 / Published online: 13 January 2022

(C) The Author(s), under exclusive licence to Springer Science+Business Media, LLC, part of Springer Nature 2022

\begin{abstract}
This study aims to examine the relationship between the levels of hopelessness, loneliness, and spiritual well-being of patients with Type 1 and Type 2 diabetes during the process of COVID-19 outbreak. The study was carried out with diabetic patients living in three different cities that are in the Eastern Anatolia region of Turkey between the dates of 15 of November and 30 of November 2020. The sample of the study consisted of 500 (Type $1, n=218$, Type $2, n=282$ ) diabetes patients. Data were collected using a demographic information form, Beck Hopelessness Scale (BHS), Loneliness Scale (UCLA-LS), and Spiritual Well-being Scale (FACIT$\mathrm{Sp}$ ). While the mean scores of hopelessness and loneliness of type 1 patients were below the moderate level, the mean scores of their spiritual well-being were found to be above the moderate level. Moreover, while the mean scores of hopelessness and loneliness in type 2 patients were below the moderate level, the mean scores of their spiritual well-being were found above the moderate level. A significant relationship was found between Type 1 and Type 2 diabetes patients' levels of hopelessness, loneliness, and spiritual well-being during the COVID-19 outbreak. It was found that as the spiritual well-being levels of Type 1 and Type 2 diabetic patients increased, the levels of their loneliness and hopelessness decreased. It is recommended that mass communication that includes spiritual care practices can be used effectively to reduce diabetes patients' levels of loneliness and hopelessness during the pandemic. In addition, while providing care to diabetes patients, it can be suggested that health professionals offer a holistic approach with initiatives that will increase diabetes patients' spiritual well-being.
\end{abstract}

Keywords Diabetes $\cdot$ Hopelessness $\cdot$ Loneliness $\cdot$ Spirituality

Mustafa Durmuş

saremeryem01@gmail.com

Extended author information available on the last page of the article 


\section{Introduction}

COVID-19 is a type of virus in the beta-coronavirus family, including SARS-CoV-2 and MERS-CoV. After a series of 'viral pneumonia' cases in Wuhan, the People's Republic of China in 2019, it quickly affected the whole world in a short time and this situation was declared as a global outbreak, that is, a "pandemic" (World Health Organization, 2020). During the period of the COVID-19 pandemic, people with chronic diseases such as diabetes experience the COVID-19 in a more severe way (Doğan et al., 2021). Outbreaks pose a challenge to psychological resilience and can lead to high-stress levels (Çiçek \& Almalı, 2020).

Diabetes mellitus (DM) is a metabolic disease that is characterized by hyperglycemia, which seriously threatens human health in all age groups, and is characterized by deterioration in carbohydrate, fat, and protein metabolism, brings many diseases, causes organ losses and the effects of the disease lasts a lifetime (Selden et al., 2020). Type 2 diabetes is the most common type of diabetes in adults and is characterized by hyperglycemia, varying degrees of insulin deficiency and resistance. Adults with type 2 diabetes are rarely characterized by significant hyperglycemia without ketoacidosis, severe dehydration, and mental fog. Type 1 diabetes is characterized by pancreatic beta cell damage that causes absolute insulin deficiency (Uygur \& Yavuz, 2017). Its incidence in adults is 5-10\%. Diabetic ketoacidosis (DKA) may be the initial manifestation in $25 \%$ of adults with newly diagnosed type 1 diabetes (Merger et al., 2013).

Since the loss of insulin secretion capacity is slower in adults, symptoms of hyperglycemia (polyuria, polydipsia) may last longer than children (Merger et al., 2013). While the number of diabetic patients in the world was 422 million as of 2014, it was estimated that this number will increase by $55 \%$ to 592 million in 2035 (Demirel et al., 2015), and one out of every ten adults will have diabetes in 2040. (Selden et al., 2020). According to the study of the Prospective Urban Rural Epidemiology (PURE) that was conducted in Turkey, it was stated that the prevalence of DM increased to $21 \%$ in Turkey for 2015 (Oguz et al., 2018). Current data on the prevalence of diabetes published by the International Diabetes Federation (IDF) show that there are approximately 7 million diabetics in the 20-79 age range in Turkey in 2020, and this figure corresponds to approximately $15 \%$ of the total adult population. (Ministry of Health of the Republic of Turkey, 2020).

Diabetes, which occurs due to changing living conditions and eating habits, causes individuals to experience physiological, psychological, and social problems (Turhan et al., 2020). In addition to the fact that treatment of diabetes is difficult, it causes patients to move away from family members, colleagues, and social environment, and feelings of loneliness and hopelessness emerge due to the physical obstacles caused by the disease. Many of the tests and treatment procedures that the patients go through throughout the process can increase the feelings of loneliness and hopelessness in patients. The feelings of loneliness and hopelessness experienced by individuals while trying to cope with the complications of diabetes should be considered as a serious problem (Demirel et al., 2015). 
Loneliness is one of the important psychosocial problems that start to occur with the diagnosis of diabetes (Demirel et al., 2015). Loneliness, which is a natural feeling for every person, can be seen in every period of life (Akgül \& Yeşilyaprak, 2018). Diabetes is a reality of life that individuals with different cultures encounter and experience to varying degrees throughout their lives (Çam et al., 2018). Patients with diabetes face many psychosocial problems during the treatment process, and one of the reasons why the patient cannot overcome these problems is the emergence of the feeling of hopelessness in individuals (Demirel et al., 2015).

Individuals with diabetes experience a sense of hopelessness as a result of negative thoughts and lose their ability to fight the disease. This situation causes a long stay in the hospital, including intensive nursing care (Güneş, 2020). It was argued that spiritual care is effective in combating the problems of hopelessness and loneliness experienced by individuals (Bini'Matillah et al., 2018).

Human beings, who have biological, psychological, spiritual, social, and cultural dimensions, should be considered (Demirel et al., 2015). Each of these dimensions possessed by human beings is interrelated and dependent on each other. With the introduction of a holistic approach to health care, the spiritual dimension has become as important as other dimensions (Selvi, 2019). The spiritual dimension contributes to the positive lifestyle of the person and has positive effects on the health and treatment of a disease because it makes individuals aware of their superiority, increases their satisfaction, decreases their anxiety, and makes them hopeful, powerful, and peaceful (Como, 2007; Y1lmaz, 2011; Y1lmaz \& Okyay, 2009). The level of spirituality of diabetic patients affects the patient's compliance with treatment, response to treatment, quality of life, morbidity, and mortality. The decrease in spiritual well-being makes it difficult to control the glycemic level (Güneş, 2020; Lynch et al., 2012).

It is thought that knowing the spiritual well-being levels of diabetic patients can reduce negative feelings and thoughts. When the literature was reviewed, no study was found that examined the relationship between loneliness, hopelessness and spiritual well-being in Type 1 and Type 2 patients. These data are thought to fill an important gap in the literature. It will also help to identify the relationship between loneliness, hopelessness, and spirituality, which are important factors in the treatment of diabetes.

\section{Methodology}

This study descriptive and cross-sectional type of research. The study was carried out with diabetic patients living in three different cities that are in the Eastern Anatolia region of Turkey between the dates of 15 of November and 30 of November 2020. The universe of the study consisted of individuals with type 1 or type 2 diabetes who complied with the criteria for participating in the study between the dates of 15 of November and 30 of November 2020. The study was completed with the convenience sampling method with 500 individuals. The convenience sampling method was preferred in selecting participants because it provides easier, cheaper, and faster data collection compared to other sampling methods (Gürbüz \& Şahin, 2014). The 
inclusion criteria for the present study are as follows: having been diagnosed with type 1 or type 2 diabetes, not having neurological disorders that would prevent the person to fill the research forms, not having received a psychiatric diagnosis (depression, personality disorder, substance abuse, etc.), and having no communication problem and being open to cooperation.

\section{Data Collection Tools}

\section{Personal Information Form}

This form was prepared by the researchers (including age, gender, educational level, employment status, profession, marital, and economic status) consists of seven questions in total.

\section{Beck Hopelessness Scale}

Beck Hopelessness Scale was developed by Beck et al. in 1974 and it was adapted to Turkish by Seber et al. In 1991. It consists of 20 items in total and the items are responded as 'yes' and 'no'. The 'yes' option given to 11 of the items $(2,4,7,9,11$, $12,14,16,17,18,20)$ get 1 point, while the option 'no' given to nine of the items $(1,3,5,6,8,10,13,15,19)$ get 1 point. The scale is assessed over 20 points in total. As the score obtained from the scale increases, the level of the hopelessness of the individual increases. BHS has three sub-dimensions: expectations about the future $(1,3,7,11,18)$, loss of motivation $(2,4,9,12,14,16,17,20)$, and hope $(5,6,8$, $10,13,15,19)$. The Beck Hopelessness Scale is a tool that measures individuals' negative perspectives about the future. Scores that range from 0-3 are considered as normal, 4-8 are mild, 9-14 are moderate, and $>15$ are considered as the severe levels of hopelessness. (Seber et al., 1993). In the present study, the Cronbach's Alpha internal consistency coefficient of Beck Hopelessness Scale was found to be 0.90 .

\section{UCLA Loneliness Scale (UCLA-LS)}

It was developed by Russell et al. (1980). The Turkish form of the scale was adapted to Turkish in 1989 by Demir. The scale was developed to determine the general loneliness level of individuals. The total score for each individual is obtained by summing the scores obtained by the individuals from all items. The scale consists of one-dimensional 20 items such as "How often do you feel that you lack companionship?" and "How often do you feel that there is no one you can turn to?", etc. The items containing positive statements $(1,5,6,9,10,15,16,19,20$. items) were scored as follows: never 4 , rarely 3 , sometimes 2 , often 1 point. On the contrary, the items containing negative expressions $(2,3,7,8,11,12,13,14,17,18$. items) were scored as follows: never 1 , rarely 2 , sometimes 3 , often 4 points. The lowest score obtained from the scale is 20 and the highest score is 80 . The higher the score, the higher the level of loneliness. 
In the present study, the Cronbach's Alpha internal consistency coefficient of UCLA Loneliness Scale was found to be 0.76 .

\section{Spiritual Well-Being Scale}

It was developed by Functional Assessment of Chronic Illness Therapy-Spiritual Well-Being Scale (FACIT-Sp). The Turkish form of the scale was adapted to Turkish in 2017 by Aktürk and colleagues. It is a scale consisting of 12 items and evaluating spiritual well-being. The scale was originally developed with two components or factors and a total (overall) score: a four-item faith component and an eight-item meaning/ peace component (Aktürk et al., 2017).

More recent work isolated three components or factors: the four-item faith subscale and separate four-item subscales each for meaning and peace. Even more recent research has shed new light on the topic, demonstrating that the three-factor model yields a better fit (Bredle et al., 2011; Canada et al., 2008; Murphy et al., 2010; Whitford \& Olver, 2012; Haugan, 2015).

The scale consists of the following questions: Meaning ( I have a reason for living, My life has been productive, I feel a sense of purpose in my life, My life lacks meaning and purpose), Peace ( I feel peaceful, I have trouble feeling peace of mind, I am able to reach down deep inside myself in order to feel comfort, I feel a sense of harmony in myself), Faith ( I find comfort in my faith, I find strength in my faith, Difficult times have strengthened my faith, I know that whatever happens with my illness, things will be okay). The scale has three sub-dimensions: meaning, peace, and faith activities ( Meaning, refers to a constant search for the meaning and purpose of life and the frequency of positive emotions and the sparseness of negative emotions, Peace is the tolerance of people and societies with different cultures, world views and lifestyles and reflecting this understanding on their lives, Belief; while belief includes the religious system or the relationship of the person with a higher power, it includes feelings towards the meaning and purpose of life regardless of any religious structure).

The concept of spirituality is defined as an experience people have about meaning, peace and faith in life in the scale. For this reason, FACIT-Sp evaluates the concepts of finding a meaning in life, having a purpose in life, and feeling peaceful. The items in the scale are responded on a five-point Likert-type scale as "none" (0 point), "very little" (1 point), "a little" ( 2 points), "quite" (3 points), "very much" (4 points). The higher the scale score, the better the spiritual well-being (Aktürk et al., 2017). In the present study, the Cronbach's Alpha internal consistency coefficient of FACIT-Sp was found to be 0.73 .

\section{Data Collection}

A questionnaire has been developed to be filled online. The questionnaires were prepared by Google Forms and the questionnaires were sent to the patients who were diagnosed with diabetes with a link (via WhatsApp and Telegram). "Questions About Socio-Demographic Characteristics of Individuals", "Beck Hopelessness 
Scale", "UCLA-Loneliness Scale", and "Spiritual Well-being Scale" were used in data collection.

\section{Data Analysis}

According to the power analysis (post hoc) performed at the end of the study to determine whether the research sample was sufficient, the power of the test was calculated as $82 \%$ with an acceptable error of 0.05 and a medium effect size. The SPSS 24 statistical analysis software was used to analyze data. Number, mean, percentage distribution, Cronbach alpha coefficient, The Independent Samples t Test and Pearson Correlation Analysis were used for data analysis.

All decisions on the statistical significance of the findings were made using a criterion alpha of 0.05 . While calculating the correlation strength in this study, the following ranges were taken as a reference: very weak correlation $(r=0-0.25)$, weak correlation $(r=0.26-0.49)$, moderate correlation $(r=0.50-0.69)$, strong correlation ( $r=0.70-0.89$ ), and very strong correlation ( $r=0.90-1.0)$ (Gürbüz \& Şahin, 2014).

Approval was obtained from the Scientific Research and Publication Ethics Committee of the University for the study (E-10879717-050.01.04-11755). The participants were informed about the following issues: the purpose of the study, the methodology of the study, the amount of time that the participants should allocate for the study, that participating in the research would not do any harm, and that the participation was completely voluntary. Upon giving this information to the participants, their written consents were taken online.

\section{Results}

In this study, the Cronbach alpha value of the Beck Hopelessness Scale was found to be 0.91 . The Cronbach alpha coefficient of the UCLA Loneliness Scale was 0.76, and the Cronbach alpha value of the Spiritual Well-Being Scale was found to be 0.72 .

The distribution of the demographic characteristics of the patients showed that (Table 1) the average age of the patients diagnosed with type 1 diabetes was $41.76 \pm 17.37$ years, $54.1 \%$ of them were women, $29.4 \%$ of them received undergraduate and graduate education, $54.6 \%$ of them were married, $75.7 \%$ of them were unemployed, $35.3 \%$ of them were self-employed, and $72.9 \%$ of them had financial problems. The average age of the patients diagnosed with type 2 diabetes was $55.73 \pm 13.51$ years, $54.3 \%$ of them were male, $37.9 \%$ of them were literate, $82.3 \%$ of them were married, $77.7 \%$ of them were not working, $48.23 \%$ of them were housewives, and $74.1 \%$ of them were financially considered to be middle-class people.

Type 1 patients had an average score of $40.03 \pm 7.72$ for loneliness. The average scores of sub-dimensions for hopelessness regarding feelings and 
Table 1 Demographic characteristics of individuals diagnosed with diabetes

\begin{tabular}{|c|c|c|c|c|}
\hline \multirow[t]{2}{*}{ Variables } & \multicolumn{2}{|c|}{ Type $1(n=218)$} & \multicolumn{2}{|c|}{ Type $2(n=282)$} \\
\hline & Number & $\%$ & Number & $\%$ \\
\hline \multicolumn{5}{|l|}{ Age } \\
\hline $18-30$ & 75 & 34.4 & 14 & 5 \\
\hline $31-40$ & 25 & 11.5 & 18 & 6.4 \\
\hline $41-50$ & 43 & 19.7 & 65 & 23 \\
\hline $51-60$ & 37 & 17.0 & 88 & 31.2 \\
\hline 61 and above & 38 & 17.4 & 97 & 34.4 \\
\hline \multicolumn{5}{|l|}{ Gender } \\
\hline Female & 118 & 54.1 & 129 & 45.7 \\
\hline Male & 100 & 45.9 & 153 & 54.3 \\
\hline \multicolumn{5}{|l|}{ Educational level } \\
\hline Literate & 49 & 22.5 & 107 & 37.9 \\
\hline Elementary & 21 & 9.6 & 35 & 12.4 \\
\hline Middle school & 39 & 17.9 & 69 & 24.5 \\
\hline High school & 45 & 20.6 & 41 & 14.5 \\
\hline $\begin{array}{l}\text { Undergraduate and } \\
\text { graduate }\end{array}$ & 64 & 29.4 & 30 & 10.6 \\
\hline \multicolumn{5}{|l|}{ Marital status } \\
\hline Married & 119 & 54.6 & 232 & 82.3 \\
\hline Single & 99 & 45.4 & 50 & 17.7 \\
\hline \multicolumn{5}{|l|}{ Employment status } \\
\hline Employed & 53 & 24.3 & 63 & 22.3 \\
\hline Unemployed & 165 & 75.7 & 219 & 77.7 \\
\hline \multicolumn{5}{|l|}{ Occupation } \\
\hline Retired & 14 & 6.4 & 53 & 18.8 \\
\hline Housewife & 75 & 34.4 & 136 & 48.2 \\
\hline Worker & 25 & 11.5 & 17 & 6 \\
\hline Civil servant & 27 & 12.4 & 28 & 9.9 \\
\hline Self-employed & 77 & 35.3 & 48 & 17 \\
\hline \multicolumn{5}{|l|}{ Financial status } \\
\hline Good & 44 & 20.2 & 58 & 20.6 \\
\hline Middle & 159 & 6.9 & 209 & 74.1 \\
\hline $\mathrm{Bad}$ & 15 & 72.9 & 15 & 5.3 \\
\hline
\end{tabular}

expectations about the future was $1.08 \pm 1.14,2.92 \pm 2.36$ for loss of motivation, $1.85 \pm 2.04$ for hope, and $5.86 \pm 5.13$ in total, and it was investigated that the average scores of the sub-dimension of spiritual well-being were 9.76 \pm 2.24 regarding 'Meaning', 9.50 \pm 2.17 regarding 'Peace', $11.77 \pm 3.60$ regarding 'Faith', and $30.60 \pm 5.70$ in total (Table 2). Type 2 patients had an average score of $41.06 \pm 8.15$ for loneliness, $1.04 \pm 1.55$ for feelings and expectations about the future, $2.87 \pm 2.16$ for loss of motivation, $1.94 \pm 2.04$ for hope, and $25.80 \pm 5.20$ in total, and it was investigated that the average score was $9.41 \pm 1.93$ regarding 
'Meaning', $8.98 \pm 2.07$ regarding 'Peace', $12.20 \pm 3.12$ regarding 'Faith', and $31.03 \pm 6.36$ in total.

While it was determined that there was no statistically significant relationship between the loneliness, feelings and expectations about the future, loss of motivation, hope, meaning, hopelessness and spiritual well-being mean scores of type 1 and type 2 diabetes patients $(p>0.05)$, statistically significant relationship was found between the mean scores of peace $(p<0.05)$, (Table 3$)$. When the relationship between average scores of loneliness, hopelessness, and spiritual well-being of the patients with Type 1 and Type 2 diabetes are examined (Tables 4 and 5), a statistically significant negative correlation was found between the sub-dimensions and total score averages of loneliness and spiritual well-being of the Type 1 and Type 2 patients.

It was investigated that there was a statistically significant negative correlation between the sub-dimension of hopelessness and total score averages of the Type 1 and Type 2 patients, and the sub-dimension of spiritual well-being and total score averages. It was also examined that there was a statistically significant positive correlation between the sub-dimensions of loneliness and hopelessness and total score averages of Type 1 and Type 2 patients. It was found in this study that as the spiritual well-being levels of the patients diagnosed with Type 1 and Type 2 diabetes increased, their feelings of loneliness and hopelessness decreased $(p<0.001)$.

Table 2 Type 1 and Type 2 The distribution of the lowest and highest scores and average scores of the patients on loneliness, hopelessness, and spiritual well-being

\begin{tabular}{|c|c|c|c|c|c|c|c|}
\hline \multirow[b]{2}{*}{ Scale } & & \multicolumn{3}{|l|}{ Type 1} & \multicolumn{3}{|l|}{ Type 2} \\
\hline & & Lowest & Highest & Average score & Lowest & Highest & Average score \\
\hline \multirow{3}{*}{ Hopelessness } & Loneliness & 26.00 & 65.00 & $40.03 \pm 7.72$ & 26.00 & 64.00 & $41.06 \pm 8.15$ \\
\hline & $\begin{array}{l}\text { Feelings and } \\
\text { Expectations } \\
\text { about the } \\
\text { Future }\end{array}$ & 0.00 & 5.00 & $1.08 \pm 1.14$ & 0.00 & 5.00 & $1.04 \pm 1.55$ \\
\hline & $\begin{array}{l}\text { Loss of Motiva- } \\
\text { tion }\end{array}$ & 0.00 & 8.00 & $2.92 \pm 2.36$ & 0.00 & 8.00 & $2.87 \pm 2.16$ \\
\hline \multirow{6}{*}{$\begin{array}{l}\text { Spiritual well- } \\
\text { being }\end{array}$} & Hope & 0.00 & 7.00 & $1.85 \pm 2.04$ & 0.00 & 7.00 & $1.94 \pm 2.04$ \\
\hline & Total & 0.00 & 20.00 & $5.86 \pm 5.13$ & 0.00 & 20.00 & $5.80 \pm 5.20$ \\
\hline & Meaning & 3.00 & 16.00 & $9.41 \pm 1.93$ & 4.00 & 12.00 & $9.76 \pm 2.24$ \\
\hline & Peace & 3.00 & 16.00 & $8.98 \pm 2.07$ & 3.00 & 16.00 & $9.50 \pm 2.17$ \\
\hline & Faith & 0.00 & 16.00 & $12.20 \pm 3.12$ & 0.00 & 16.00 & $11.77 \pm 3.60$ \\
\hline & Total & 10.00 & 47.00 & $30.60 \pm 5.70$ & 10.00 & 47.00 & $31.03 \pm 6.36$ \\
\hline
\end{tabular}


Table 3 Comparison of the mean scores of loneliness, hopelessness, and spiritual well-being of Type 1 and Type 2 diabetes patients

\begin{tabular}{lllll}
\hline \multirow{3}{*}{ Scale } & & Type 1 & Type 2 & \\
& & $\bar{X}_{ \pm S D}$ & $\bar{X}_{ \pm S D}$ & $t$ test and $p$ value \\
\hline \multirow{4}{*}{ Hopelessness } & Loneliness & $40.03 \pm 7.72$ & $41.06 \pm 8.15$ & $t=1.43, p=0.216$ \\
& Feelings and Expecta- & $1.08 \pm 1.14$ & $1.04 \pm 1.55$ & $t=1.22, p=0.220$ \\
& tions about the Future & & & \\
& Loss of Motivation & $2.92 \pm 2.36$ & $2.87 \pm 2.16$ & $t=1.17, p=0.239$ \\
& Hope & $1.85 \pm 2.04$ & $1.94 \pm 2.04$ & $t=1.22, p=0.221$ \\
& Total & $5.86 \pm 5.13$ & $5.80 \pm 5.20$ & $t=-.014, p=0.989$ \\
& Meaning & $9.41 \pm 1.93$ & $9.76 \pm 2.24$ & $t=1.89, p=0.058$ \\
& Peace & $8.98 \pm 2.07$ & $9.50 \pm 2.17$ & $t=2.69, p=0.007$ \\
& Faith & $12.20 \pm 3.12$ & $11.77 \pm 3.60$ & $t=-1.45, p=0.146$ \\
& Total & $30.60 \pm 5.70$ & $31.03 \pm 6.36$ & $t=0.795, p=0.427$ \\
\hline
\end{tabular}

Table 4 The relationship between loneliness, hopelessness and spiritual well-being of Type 1 patients

\begin{tabular}{|c|c|c|c|c|c|c|}
\hline & & \multicolumn{5}{|c|}{ Type 1 spiritual well-being } \\
\hline & & Meaning & Peace & Faith & Total & Loneliness \\
\hline \multirow[t]{2}{*}{ Loneliness } & & $r=-.400^{*}$ & $r=-.290^{*}$ & $r=-.378^{*}$ & $r=-.453^{*}$ & 1 \\
\hline & & $p=0.000$ & $p=0.000$ & $p=0.000$ & $p=0.000$ & \\
\hline \multirow[t]{8}{*}{ Hopelessness } & $\begin{array}{l}\text { Feelings and expecta- } \\
\text { tions about the } \\
\text { Future }\end{array}$ & $r=-.476^{*}$ & $r=-.400^{*}$ & $r=-.339^{*}$ & $r=-.496^{*}$ & $r=.908^{*}$ \\
\hline & & $p=0.000$ & $p=0.000$ & $p=0.000$ & $p=0.000$ & $p=0.000$ \\
\hline & Loss of motivation & $r=-.386^{*}$ & $r=-.330^{*}$ & $r=-.265^{*}$ & $r=-.398^{*}$ & $r=.807 *$ \\
\hline & & $p=0.000$ & $p=0.000$ & $p=0.000$ & $p=0.000$ & $p=0.000$ \\
\hline & Hope & $r=-.580^{*}$ & $r=-.505^{*}$ & $r=-.300^{*}$ & $r=-.546^{*}$ & $r=.826^{*}$ \\
\hline & & $p=0.000$ & $p=0.000$ & $p=0.000$ & $p=0.000$ & $p=0.000$ \\
\hline & Total & $r=-.535^{*}$ & $r=-.459 *$ & $r=-.332 *$ & $r=-.533^{*}$ & $r=.622^{*}$ \\
\hline & & $p=0.000$ & $p=0.000$ & $p=0.000$ & $p=0.000$ & $p=0.000$ \\
\hline
\end{tabular}

$* p<0.01$ significant

\section{Discussion}

It is thought that this study will provide information about the levels of hopelessness, loneliness, and spiritual well-being of diabetic patients and will contribute to the studies to be done in this field. Hopelessness is a common symptom of depression and it is seen in about $40 \%$ of patients with diabetes. It is emphasized that hopelessness causes negative thoughts in individuals and causes increased suicide rates (Chen et al., 2020).

It was found in this study that the hopelessness levels of Type 1 and Type 2 diabetes patients were below the moderate level. No previous study has investigated 
Table 5 The relationship between loneliness, hopelessness and spiritual well-being of Type 2 patients

\begin{tabular}{|c|c|c|c|c|c|c|}
\hline & & \multicolumn{4}{|c|}{ TYPE 2 spiritual well-being } & \multirow[t]{2}{*}{ Loneliness } \\
\hline & & Meaning & Peace & Faith & Total & \\
\hline \multirow[t]{2}{*}{ Loneliness } & & $r=-.577 *$ & $r=-.481^{*}$ & $r=-.475$ & $r=-.630^{*}$ & 1 \\
\hline & & $p=0.000$ & $p=0.000$ & $p=0.000$ & $p=0.000$ & \\
\hline \multirow[t]{8}{*}{ Hopelessness } & Feelings and expecta- & $r=-.509 *$ & $r=-.518 *$ & $r=-.458^{*}$ & $r=-.611^{*}$ & $r=.903^{*}$ \\
\hline & $\begin{array}{l}\text { tions about the } \\
\text { future }\end{array}$ & $p=0.000$ & $p=0.000$ & $p=0.000$ & $p=0.000$ & $p=0.000$ \\
\hline & Loss of motivation & $r=-.387 *$ & $r=-.460 *$ & $r=-.342^{*}$ & $r=-.485^{*}$ & $r=.831^{*}$ \\
\hline & & $p=0.000$ & $p=0.000$ & $p=0.000$ & $p=0.000$ & $p=0.000$ \\
\hline & Hope & $r=-.578^{*}$ & $r=-.532 *$ & $r=-.409^{*}$ & $r=-.612 *$ & $r=.788^{*}$ \\
\hline & & $p=0.000$ & $p=0.000$ & $p=0.000$ & $p=0.000$ & $p=0.000$ \\
\hline & Total & $r=-.547 *$ & $r=-.563 *$ & $r=-.445^{*}$ & $r=-.633^{*}$ & $r=.659 *$ \\
\hline & & $p=0.000$ & $p=0.000$ & $p=0.000$ & $p=0.000$ & $p=0.000$ \\
\hline
\end{tabular}

$* p<0.01$ significant

the hopelessness levels of patients with Type 1 and Type 2 diabetes during the pandemic period. Yilmaz and Alpar carried out a study in Turkey before the pandemic period and found that the hopelessness levels of Type 2 diabetes patients were below moderate level (Y1lmaz, 2010). Robinson et al. (2020) conducted a study with individuals who had chronic diseases before the pandemic and the researchers investigated that the hopelessness levels of the patients were quite high (Robinson et al., 2020). In another study, it was found that $17.2 \%$ of adults diagnosed with Type 1 and Type 2 diabetes were hopeless (Anastasiades et al., 2016). It was reported that during the pandemic period, social ties were strengthened and the tendency toward religion increased (Yağlı, 2020).

It is stated that the presence of social supports and being married can increase the level of hope in dealing with psychological problems in diabetes patients (Özdemir et al., 2019). Some studies argued that married individuals are more hopeful than singles (İmiroğlu et al., 2021; Kocaman, 2019). Kocaman (2019) indicated that the reason why married individuals have higher levels of hope compared to singles is due to the fact that they have more positive plans for the future and higher perceptions of support and feelings of trust in their social relations (Kocaman, 2019). It is thought that most of the diabetes patients participating in this study received adequate social support because they were married, and thus the participants' level of hopelessness was low.

Diabetes can lead to loneliness and, in turn, loneliness may be a risk factor for worsening the treatment outcomes of diabetes (Petitte et al., 2015). It was found in this study that loneliness levels of Type 1 and Type 2 diabetic patients were below the moderate level and loneliness levels of individuals with Type 2 diabetes were higher.

In a study that was conducted by Joensen et al., it was reported that Type 1 and Type 2 diabetes patients experienced more anxiety about COVID-19 and diabetes during the process of pandemic, and most of them felt lonely and needed care for 
loneliness (Joensen et al., 2020). Kobos et al. reported that there was no significant difference between the loneliness levels of Type 1 and Type 2 diabetic patients, and patients generally experienced moderate level of loneliness, and approximately onefifth (16\%) of the patients experienced intense loneliness (Kobos et al., 2021). Kusaslan Avci conducted a study before the pandemic and, like this study, found that the loneliness levels of individuals with Type 1 and Type 2 diabetes were below the moderate level, while, unlike this study, individuals with Type 1 diabetes had higher loneliness levels (Kusaslan Avci, 2018). It has been emphasized in other studies that patients with Type 1 diabetes experienced higher levels of loneliness, unlike this study (Jones et al., 2016; Zhou et al., 2017).

It was indicated by the researchers that adults' limited face-to-face interactions within the family and lack of regular activities would lead to increased loneliness (Frenkel-Yosef et al., 2020). Luchetti et al. (2020) emphasized that individuals who had chronic diseases and lived alone felt more alone. Morrow-Howell et al. emphasized that family and intergenerational relationships developed during the pandemic period and that the pandemic was effective in strengthening social ties (MorrowHowell et al., 2020).

In this study, it was found that Type 1 and Type 2 diabetic patients had above moderate level of spiritual well-being. Faghani et al. investigated that the spiritual well-being levels of the Type 2 diabetic patients were above the moderate level, similar to the findings of the current study (Faghani et al., 2018).

Javanmardifard et al. carried out a study with Type 2 diabetic patients and reported that most of the participants had moderate spiritual well-being, unlike the findings of this study (Javanmardifard et al., 2020). In this study, it was found that there was a negative significant relationship between loneliness and spiritual wellbeing levels of Type 1 and Type 2 diabetic patients. Other published studies indicated that spiritual well-being reduced loneliness (Dashtbozorgi et al., 2016; Gallegos \& Segrin, 2019; Pandya, 2020).

The COVID-19 crisis makes it very difficult for individuals to cope with feelings of loneliness. Studies conducted in this process indicated that people had difficulty in adapting to a lifestyle that was incompatible with their social nature and that their level of loneliness may increase due to this crisis (Brooks et al., 2020). It is suggested that spiritual care may have an impact on the loneliness levels of diabetic patients.

In this study, a significant negative correlation was found between the hopelessness levels and spiritual well-being levels of patients with Type 1 and Type 2 diabetes. It was argued that there was a significant negative relationship between spiritual well-being and hopelessness, and spiritual well-being provided protection against hopelessness (Saarelainen, 2019). Spiritual care is regarded as a life-enhancing factor and improves the patients' coping skills to better struggle with adversity. Moreover, it was argued that it can boost the patients' hopes for the future (Vincensi, 2019). It is thought that spiritual care may have an impact on the hopelessness levels of diabetic patients.

In this study, it was found that there was a negative significant relationship between loneliness and spiritual well-being levels of Type 1 and Type 2 diabetic patients. In some studies, like the current study, it was found that spiritual well-being 
reduces loneliness (Dashtbozorgi et al., 2016; Gallegos \& Segrin, 2019; Pandya, 2020). It can be said that spirituality is effective in reducing the loneliness of diabetic patients.

\section{Limitations of the Study}

FACIT-Sp was applied to assess the spiritual well-being of patients with Type 1 and Type 2 diabetes participating in this study. FACIT-Sp is intertwined with concepts such as the purpose of life, meaning and feeling at peace. Significant differences can be seen among patients with Type 1 and Type 2 diabetes in their perception of the purpose and meaning of life. Therefore, it may not be possible to generalize the results of the study to all patients with Type 1 and Type 2 diabetes. In addition, since FACIT-Sp evaluates the concept of spirituality through positive mental states such as meaning in life, finding purpose, and feeling peaceful, it is an expected result that the scale will be associated with positive emotions such as hope. This is one of the limitations of the study as it may cause bias in the research findings.

Individuals with limited digital literacy could not be reached. It was not known if the participants had other chronic diseases. It was not known if other people in the same house were diagnosed with COVID-19. In addition, the fact that only participants who were not diagnosed with COVID-19 participated in this study is among the limitations.

\section{Conclusion}

It was found in this study that the loneliness and hopelessness levels of Type 1 and Type 2 diabetic patients were below the moderate level, while their spiritual wellbeing levels were above the moderate level during the pandemic period. Moreover, it was investigated that there was a significant negative correlation between the levels of loneliness and hopelessness and spiritual well-being of Type 1 and Type 2 diabetic patients during the COVID-19 pandemic. Based on these results, it can be said that Type 1 diabetic patients may experience more loneliness because of their treatment regimens and some problems that come with these treatment regimens such as higher stress levels, hypoglycemia or hyperglycemic coma, and a higher risk of acute complications.

It was thought that during the process of pandemic, the diabetic patients' spending their time with family members at home reduced their levels of hopelessness and loneliness. It is recommended that relevant initiatives that can boost hope strengthen social ties, and support spirituality should be planned for Type 1 and Type 2 diabetic patients during the pandemic. Therapeutic practices can be offered online during the pandemic to improve mental health care. In addition, phone and video conference calls can be offered to the patients, in which they see and talk to the people they love. 
Acknowledgements The authors thank the patients with Type 1 and Type 2 diabetes who participated in this study.

Author Contributions Mustafa DURMUŞ contributed to the design, conducted the searches, screening and data extraction, and contributed to the analysis and write-up of the manuscript. Necmettin ÇiFTCi, Abdullah GERÇEK and YUSUF DURMUŞ conducted the searches, screening and contributed to writeup of the manuscript.

Funding The author(s) received no financial support for the research, authorship, and/or publication of this article.

\section{Declarations}

Conflict of interest The author(s) declared no potential conflicts of interest concerning the research, authorship, and/or publication of this article.

Ethical Approval Approval was obtained from Muş Alparslan University Scientific Research and Publication Ethics Committee for the research (number: E-10879717-050.01.04-11,755). Verbal consent to participate in the research was obtained from the individuals by giving information about the purpose of the research, the method, the time they would spare for the research, and by declaring that participating in the research would not do any harm and that the participation was completely voluntary.

\section{References}

Akgül, H., \& Yeşilyaprak, B. (2018). Yalnızlığı azaltma psiko-eğitim programının yaşlıların yalnızlık düzeyine etkisi. OPUS Uluslararası Toplum Araştırmaları Dergisi, 8(14), 11-52. https://doi.org/10. 26466/opus.401331

Akturk, U., Erci, B., \& Araz, M. (2017). Functional evaluation of treatment of chronic disease: validity and reliability of the turkish version of the spiritual well-being scale. Palliative \&amp; Supportive Care, 15(6), 684-692. https://doi.org/10.1017/S1478951517000013

Anastasiades, M. H., Gupton, O., Fritz, A., Caldaza, P., \& Stillman, M. (2016). Diabetes, depression and nonadherence: xploring hopelessness as a meditating factor: a preliminary study. Mental Health in Family Medicine, 12, 243-249. http://www.mhfmjournal.com/pdf/diabetes-depression-and-nonad herence-exploring-hopelessness-as-a-meditating-factor-a-preliminary-study.pdf

Bini'Matillah, U., Susumaningrum, L. A., \& Ala, M. Z. (2018). Correlation between spirituality and loneliness in elderly in the upt pelayanan sosial tresna werdha. Pustaka Kesehatan, 6(3), 438-445. https://jurnal.unej.ac.id/index.php/JPK/article/view/11589

Bredle, J. M., Salsman, J. M., Debb, S. M., et al. (2011). Spiritual well-being as a component of healthrelated quality of life: the functional assessment of chronic illness therapy-spiritual well-being scale (FACIT-Sp). Religions., 2(1), 77-94.

Brooks, S. K., Webster, R. K., Smith, L. E., Woodland, L., Wessely, S., Greenberg, N., \& Rubin, G. J. (2020). The psychological impact of quarantine and how to reduce it: rapid review of the evidence. The Lancet, 395, 912-920. https://doi.org/10.1016/S0140-6736(20)30460-8

Çam, C., Atay, E., \& Işıklı, B. (2018). Yaşlılarda yalnızlık ve yaşam kalitesi. Eskişehir Türk Dünyası Uygulama ve Araştırma Merkezi Halk Sağlı̆̆ı Dergisi, 3(2),49-67. https://dergipark.org.tr/en/pub/ estudamhsd/issue/39508/466093?publisher=estudam

Canada, A. L., Murphy, P. E., Fitchett, G., et al. (2008). A 3-actor model for the FACIT-Sp. PsychoOncology., 17(9), 908-916.

Chen, Y., Koh, H. K., Kawachi, I., Botticelli, M., \& VanderWeele, T. J. (2020). Religious service attendance and deaths related to drugs, alcohol, and suicide among US health careprofessionals. JAMA Psychiatry, 77(7), 737-744. https://doi.org/10.1001/jamapsychiatry.2020.0175 
Çiçek, B., \& Almalı, V. (2020). COVID-19 Pandemisi sürecinde kaygı öz-yeterlilik ve psikolojik iyi oluş arasındaki ilişki: Özel sektör ve kamu çalışanları karşılaştırması. Electronic Turkish Studies, 15(4), 241-260. https://doi.org/10.7827/TurkishStudies.43492

Como, J. M. (2007). Spiritual practice: A literature review related to spiritual health and health outcomes. Holistic Nursing Practice, 21(5), 224-236. https://doi.org/10.1097/01.HNP.0000287986.17344.02

Dashtbozorgi, Z., Sevari, K., \& Safarzadeh, S. (2016). Effectiveness of Islamic spiritual therapy on the feeling of loneliness and death anxiety in elderly people. Aging Psychology, 2(3), 177-186. https:// jap.razi.ac.ir/m/article_616.html?lang=en

Demir, A. (1989). UCLA yalnızlık ölçeğinin geçerlik ve güvenirliği. Psikoloji Dergisi, 7(23), 14-18. https://open.metu.edu.tr/handle/11511/81352

Demirel, A. C., Altınbaş, M., Taşyürek, Z., Nuri, A., \& Aaslan, K. (2015). Metastaz durumuna göre kanser hastalarının yanlızlık ve umutsuzlıuk düzeyleri. Tıbbi Sosyal Hizmet Dergisi,(5), 6-15. https://dergipark.org.tr/en/pub/tshd/issue/52283/684093

Doğan, K., Bolat, S., \& Doğan, H. O. (2021). Obezite, metabolik sendrom, diyabet ve COVID-19 ilişkisi. In D. Yücel (Ed.), COVID-19 pandemisinde tıbbi biyokimyanın artan rolü 1 (pp. 63-70). Türkiye Klinikleri.

Faghani, S., Shamsalinia, A., Ghaffari, F., \& Yadegari, N. (2018). The relationship between spiritual well-being and life orientation in elderly people with type 2 diabetes. Journal of Gerontology and Geriatrics, 66, 142-148. http://www.jgerontology-geriatrics.com/article/view/86

Frenkel-Yosef, M., Maytles, R., \& Shrira, A. (2020). Loneliness and its concomitants among older adults during the COVID-19 pandemic. International Psychogeriatrics, 32(10), 1257-1259. https://doi. org/10.1017/S1041610220003476

Gallegos, M. L., \& Segrin, C. (2019). Exploring the mediating role of loneliness in the relationship between spirituality and health: Implications for the Latino health paradox. Psychology of Religion and Spirituality, 11(3), 308-318. https://doi.org/10.1037/rel0000180

Güneş, D. (2020). Birinci basamağa başvuran tip 2 diabetes mellitus olan hastalarda yaşam kalitesi ile umutsuzluk arasındaki ilişki (Yükseklisans tezi, Erzincan Üniversitesi). Erzincan. http://earsiv.erzin can.edu.tr/xmlui/handle/20.500.12432/4066

Gürbüz, S., \& Şahin, F. (2014). Research methods in social sciences (pp. 100-130). Seçkin Publishing.

Haugan, G. (2015). The FACIT-Sp Spiritual Well-Being Scale: an investigation of the dimensionality, reliability and construct validity in a cognitively intact nursing home population. Scandinavian Journal of Caring Sciences., 29, 152-164.

İmiroğlu, A., Demir, R., \& Murat, M. (2021). Cognıtıve flexıbılıty, mındfulness and hope as predıctors of psychological well-being. Electronic Journal of Social Sciences, 20(80), 2037-2057. https://doi.org/ 10.17755/esosder.859555

Javanmardifard, S., Heidari, S., Sanjari, M., Yazdanmehr, M., \& Shirazi, F. (2020). The relationship between spiritual well-being and hope, and adherence to treatment regimen in patients with diabetes. Journal of Diabetes \&amp; Metabolic Disorders, 19, 941-950. https://doi.org/10.1007/ s40200-020-00586-1

Joensen, L., Madsen, K., Holm, L., Nielsen, K., Rod, M., Petersen, A., \& Willaing, I. (2020). Diabetes and COVID-19: psychosocial consequences of the COVID-19 pandemic in people with diabetes in Denmark - what characterizes people with high levels of COVID-19-related worries? Diabetic Medicine, 37(7), 1146-1154. https://doi.org/10.1111/dme.14319

Jones, A., Olsen, M. Z., Perrild, H. J., \& Willaing, I. (2016). The psychological impact of living with diabetes: descriptive findings from the DAWN2 study in Denmark. Primary Care Diabetes, 10(1), 83-86. https://doi.org/10.1016/j.pcd.2015.03.008

Kobos, E., Szewczyk, A., Kokoszka-Paszkot, J., \& Dziedzic, B. (2021). Factors associated with loneliness in patients with diabetes mellitus. Nursing Open, 8(1), 517-524. https://doi.org/10.1002/nop2. 655

Kocaman, E. N. (2019). Bir grup yetişkinde umut ve psikolojik iyi oluş arasındaki ilişkinin farklı değişkenler açısından incelenmesi. (Yüksek lisans tezi, İstanbul Sabahattin Zaim Üniversitesi). İstanbul. https://openaccess.izu.edu.tr/xmlui/handle/20.500.12436/395

Kusaslan Avci, D. (2018). Evaluation of the relationship between loneliness and medication adherence in patients with diabetes mellitus: a cross-sectional study. Journal of International Medical Research, 46(8), 3149-3161. https://doi.org/10.1177/0300060518773223

Luchetti, M., Lee, J. H., Aschwanden, D., Sesker, A., Strickhouser, J. E., Terracciano, A., \& Sutin, A. R. (2020). The trajectory of loneliness in response to COVID-19. American Psychologist, 75(7), 897-908. https://doi.org/10.1037/amp0000690 
Lynch, C. P., Hernandez-Tejada, M. A., Strom, J. L., \& Egede, L. E. (2012). Association between spirituality and depression in adults with type 2 diabetes. The Diabetes Educator, 38(3), 427-435. https:// doi.org/10.1177/0145721712440335

Merger, S. R., Leslie, R. D., \& Boehm, B. O. (2013). The broad clinical phenotype of Type 1 diabetes at presentation. Diabetic Medicine, 30(2), 170-178. https://doi.org/10.1111/dme.12048

Ministry of Health of the Republic of Turkey. (2020, November 29). Dünya Diyabet Günü. https:// sggm.saglik.gov.tr/TR-76887/dunya-diyabet-gunu-2020.html.

Morrow-Howell, N., Galucia, N., \& Swinford, E. (2020). Recovering from the COVID-19 pandemic: a focus on older adults. Journal of Aging \&amp; Social Policy, 32(4-5), 526-535. https://doi. org/10.1080/08959420.2020.1759758

Murphy, P. E., Canada, A. L., Fitchett, G., et al. (2010). An examination of the 3-factor model and structural invariance across racial/ethnic groups for the FACIT-Sp: a report from the American Cancer Society's Study of Cancer Survivors-II (SCS-II). Psycho-Oncology., 19(3), 264-272.

Oguz, A., Telci Caklili, O., Tumerdem Calik, B., \& Investigators, P. (2018). The prospective urban rural epidemiology (PURE) study: PURE Turkey. Türk Kardiyoloji Dernegi Arsivi, 46(7), 613623. https://doi.org/10.5543/tkda.2018.32967

Özdemir, A., Kavak, F., \& Gültekin, A. (2019). Tip II diyabet hastalarında algılanan sosyal destek ile öz etkililik durumunun belirlenmesi. Turkiye Klinikleri J Nurs Sci., 11(3), 305-312. https://doi. org/10.5336/nurses.2019-64774

Pandya, S. P. (2020). Spiritual counselling mitigates loneliness and promotes affect balance for older empty nester couples: A study in some international cities. Counselling and Psychotherapy Research. https://doi.org/10.1002/capr.12342

Petitte, T., Mallow, J., Barnes, E., Petrone, A., Barr, T., \& Theeke, L. (2015). A systematic review of loneliness and common chronic physical conditions in adults. The Open Psychologyjournal, 8(2), 113. https://doi.org/10.2174/1874350101508010113

Robinson, M. A., Kim, I., Mowbray, O., \& Washington, T. (2020). The effects of hopelessness on chronic disease among african americans and caribbean blacks: findings from the national survey of american life (NSAL). Community Mental Health Journal, 56(4), 753-759. https://doi.org/10. 1007/s 10597-019-00536-Z

Russell, D., Peplau, L. A., \& Cutrona, C. E. (1980). The revised UCLA Loneliness Scale: Concurrent and discriminant validity evidence. Journal of Personality and Social Psychology, 39(3), 472-480. https://doi.org/10.1037/0022-3514.39.3.472

Saarelainen, S. M. (2019). Landscapes of hope and despair: Stories of the future of emerging adults in cancer remission. Journal of Pastoral Theology, 29(2), 67-84. https://doi.org/10.1080/10649 867.2019.1632403

Seber, G., Dilbaz, N., Kaptanoğlu, C., \& Tekin, D. (1993). Ümitsizlik Ölçeği: Geçerlik güvenirlik. Kriz Dergisi, 1(3), 134-138. https://dergipark.org.tr/tr/pub/kriz/issue/41113/496925

Selden, G., Simge, Ö., Avdal, E. Ü., Dündar, B. N., \& Pamuk, B. Ö. (2020). Diyabette tıbbi bakım standartlarında değişiklikler. İzmir Katip Çelebi Üniversitesi Să̆lık Bilimleri Fakültesi Dergisi, 5(1), 25-29. https://dergipark.org.tr/tr/pub/ikcusbfd/issue/54199/635020

Selvi, Y. (2019). Terminal dönemdeki hastalara bakım veren hemşirelerin ölüme karşı tutumları, manevi destek algıları ve bunlar arasındaki ilişkinin incelenmesi( Yüksek Lisans, Nevşehir Hacı Bektaş Veli Üniversitesi). Nevşehir https://acikerisim.nevsehir.edu.tr/handle/20.500.11787/449

Turhan, S., Özkan, Y., Yürekli, B. S., Suner, A., \& Doğu, E. (2020). Sınıf dengesizliği varlığında hastalık tanısı için kolektif öğrenme yöntemlerinin karşılaştırılması: Diyabet tanısı örneği. Turkiye Klinikleri Journal of Biostatistics. https://doi.org/10.5336/biostatic.2019-66816

Uygur, M. M., \& Yavuz, D.G. (2017). Diyabet tanısı ve sınıflandırılması. Turkiye Klinikleri J Nutr Diet-Special Topics, 3(3), 120-129. https://www.turkdiab.org/admin/PICS/webfiles/Diyabet_ tani_ve_tedavi_kitabi.pdf

Vincensi, B. B. (2019). Interconnections: spirituality, spiritual care, and patient-centered care. AsiaPacific Journal of Oncology Nursing, 6(2), 104-110. https://doi.org/10.4103/apjon.apjon_48_18

Whitford, H. S., \& Olver, I. N. (2012). The multidimensionality of spiritual wellbeing: peace, meaning, and faith and their association with quality of life and coping in oncology. Psycho-Oncology., 21(6), 602-510.

World Health Organization.(2020, July 22). Coronavirus Disease. https://www.who.int/

Yağlı, N. (2020). A psychosocial evaluation on the relationship between grief and religion during the pandemic period of COVID-19. Turkish Studies, 15(6), 925-947. https://doi.org/10.7827/Turki shStudies.45119 
Yılmaz, M., \& Okyay, N. (2009).Hemşirelerin maneviyat ve manevi bakıma ilişkin görüşleri. Hemşirelikte Araştırma Geliştirme Dergisi, 11(3), 41-52. https://dergipark.org.tr/en/pub/hemar ge/issue/52706/695074

Yılmaz, E. (2010). Tip 2 diyabet hastalarının uyumsuzluk düzeyleri ile özbakım gücü ilişkisi (Yüksek lisans Tezi, M.Ü. Sağlık Bilimleri Enstitüsü). İstanbul. https://www.proquest.com/intermedia teredirectforezproxy

Yılmaz, M. (2011). Holistik bakımın bir boyutu: Spiritualite, doğasi ve hemşirelikle ilişkisi. Anadolu Hemşirelik ve Sağllk Bilimleri Dergisi, 14(2), 61-70. https://dergipark.org.tr/en/pub/ataunihem/ issue/2653/34075

Zhou, H., Zhu, J., Liu, L., Li, F., Fish, A. F., Chen, T., \& Lou, Q. (2017). Diabetes-related distress and its associated factors among patients with type 2 diabetes mellitus in China. Psychiatry Research, 252, 45-50. https://doi.org/10.1016/j.pcd.2015.03.008

Publisher's Note Springer Nature remains neutral with regard to jurisdictional claims in published maps and institutional affiliations.

\section{Authors and Affiliations}

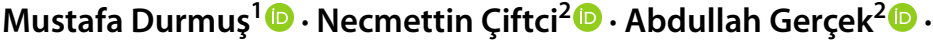 Yusuf Durmuş}

1 Department of Gerontology Faculty of Health Sciences, Mus Alparslan University, 49100 Muş, Turkey

2 Health Services Vocational School, Mus Alparslan University, 49100 Muş, Turkey

3 Malazgirt Vocational School, Muş Alparslan University, 49100 Muş, Turkey 